\title{
UMA RELEITURA DO INCESTO DIANTE DE UM NOVO CONTEXTO SOCIOFAMILIAR
}

\section{A NEW VISION OF INCEST IN FRONT OF A NEW SOCIAL-FAMILY CONTEXT}

${ }^{1}$ Isabela Farah Valadares

\section{RESUMO}

Este artigo, que adota a metodologia de pesquisa bibliográfica, visa analisar as razões que levaram o incesto a ser considerado uma lei universal, bem como um interdito necessário para a vida em sociedade, e, a partir deste prisma, apresentar uma nova visão em relação aos impedimentos matrimoniais vinculados ao parentesco. Para tanto, realiza-se um estudo acerca da maternidade e da paternidade como uma função e da forma como os impedimentos matrimoniais foram estabelecidos na legislação brasileira vigente, questionando-se se são compatíveis com a verdadeira função que cada indivíduo exerce no contexto familiar atual. Por fim, demonstra-se a necessidade de proceder a uma revisão das regras atuais do incesto, sob a justificativa de que, se foi uma lei criada para a manutenção da vida em grupo, isso requer um convívio e uma relação social entre os membros desse grupo para que tais proibições façam sentido e sejam reconhecidas como válidas por eles.

Palavras-chave: Incesto, Impedimentos matrimoniais, Função parental, Relação sociofamiliar

\section{ABSTRACT}

This article, which adopts the literature search methodology aims to analyze reasons for incest to be considered a universal law as well as an interdict necessary for life in society, and, from this perspective, presenting a new vision for matrimonial impediments linked to Relatives. Therefore, is realized a study of motherhood and fatherhood as a function and the way that marital impediments were established in the Brazilian legislation, questioning whether they are compatible with the true role that each individual plays within the current family context. Finally, it demonstrates the necessity for a review on current incest rules, on the grounds that it was a law created to maintain group life, this requires a convivial and social relations between members of the group, to such prohibitions that make sense and are recognized as valid for them.

Keywords: Incest, Impediments to marriage, Parental function, Social-family relationship

\footnotetext{
${ }^{1}$ Mestra em Direito em Pontifícia Universidade Católica de Minas Gerais, PUC Minas, Minas Gesrais, MG. (Brasil). Professor no Instituto Belo Horizonte de Ensino Superior, IBHES, Minas Gerais, MG, (Brasil). E-mail: belafarah@hotmail.com.
} 


\section{INTRODUÇÃO}

O incesto, tema polêmico, que abrange as ordens cultural, moral e jurídica de uma sociedade, sempre foi um assunto que despertou o interesse da Antropologia, da Psicanálise e do Direito. Entretanto, pela dificuldade de uma análise objetiva e sem preconceitos e interferência do ambiente em que se vive, chegar a conclusões imparciais quanto às circunstâncias relacionadas ao incesto se torna um desafio.

A partir do olhar da Antropologia e da Psicanálise, verifica-se que sempre houve proibições acerca de determinadas relações sexuais entre os seres humanos. $\mathrm{O}$ mais curioso é que, mesmo sendo isso um fato universal, tais relações não são decorrentes da natureza humana, e sim de sua cultura.

O grande problema é descobrir qual a razão da constante proibição do incesto e qual a finalidade desse interdito, que tanto se diversificou ao longo da história.

O incesto sempre esteve necessariamente vinculado ao sistema de parentesco utilizado em cada tempo e a cada sociedade diferente, verificando-se que as constantes mudanças nas regras de parentesco influenciam também as mudanças nas regras do incesto.

No ordenamento brasileiro, apesar de ser reprovado pelo Direito Civil, o incesto não ocorre no Direito Penal, não sendo as relações incestuosas tipificadas pela legislação brasileira como crime. Porém, as consequências no âmbito civil são graves e de interesse público, tornando-se nulo qualquer tipo de união que afronte os impedimentos resultantes de parentesco.

A partir do entendimento da razão que levou à imposição da proibição do incesto, bem como da maneira como as relações de parentesco eram determinadas nos primórdios da civilização, torna-se imprescindível analisar se os vínculos de parentescos atuais representam alguma proximidade e interação entre o núcleo familiar, como antigamente representavam, e se o incesto, baseado nos moldes desses parentescos, cumpre com a sua função primordial de manter a união do grupo e a vida em sociedade.

\section{INCESTO: UMA LEI UNIVERSAL}

No dicionário da língua portuguesa, incesto significa "União sexual entre parentes (consanguíneos ou afins), condenada pela lei, pela moral e pela religião" 
(TREVISAN, 2015). No âmbito da psicanálise, “designa-se pelo termo 'incesto' uma relação sexual interdita entre parentes próximos, sendo a interdição baseada no plano moral e eventualmente formulada no plano jurídico" (MIJOLLA, 2005, p. 938).

Em ambos os conceitos, pode-se perceber que o significado do incesto decorre necessariamente do significado de parentesco. A relação de parentesco hoje aceita em nossa sociedade nada mais é que o resultado decorrente da exigência de sistematização que todo pensamento humano apresenta.

Desde as civilizações mais primitivas até a atualidade, o ser humano sempre procurou organizar e classificar tudo ao seu redor. Entretanto, para que tais classificações sejam realmente compreendidas não basta identificar o nome e as características atribuídas a cada símbolo; é indispensável entender o papel que é atribuído aos elementos de cada sistema classificatório.

\footnotetext{
Não basta identificar com exatidão cada animal, cada planta, pedra, corpo celeste ou fenômeno natural evocado nos mitos e no ritual - tarefas múltiplas para as quais o etnólogo raramente está preparado - é preciso saber também que papel cada cultura lhe atribui no interior de um sistema de significações (LÉVI-STRAUSS, 2011, p. 71).
}

Apesar de os sistemas de classificação serem criados a partir de semelhanças ou diferenças entre as espécies naturais, eles também “podem estar desigualmente situados em relação ao arbitrário e ao motivado, sem que esse último deixe de ser aí operante" (LÉVI-STRAUSS, 2011, p. 186).

A partir de estudos aprofundados, Friedrich Engels, em 1884, com base nas descobertas de campo de Lewis Henry Morgan, apontou que as relações de parentesco utilizadas por muitos povos selvagens e bárbaros que ainda habitavam a América, Ásia, África e Austrália não eram compatíveis com as relações de parentesco utilizadas pelas sociedades civilizadas.

A descendência de semelhante casal era patente e reconhecida por todos; nenhuma dúvida podia surgir quanto às pessoas a quem se aplicavam os nomes de pai, mãe, filho, filha, irmão ou irmã. Mas, o uso atual desses nomes 
constituía uma contradição. O iroquês não somente chama filhos e filhas aos seus próprios, mas, ainda, aos de seus irmãos, os quais, por sua vez, o chamam pai. Os filhos de suas irmãs; pelo contrário, ele os trata como sobrinhos e sobrinhas, e é chamado de tio por eles. Inversamente, a iroquesa chama filhos e filhas os de suas irmãs, da mesma forma que os próprios, e aqueles, como estes, chamam-na mãe. Mas chama sobrinhos e sobrinhas os filhos de seus irmãos, os quais a chamam de tia. Do mesmo modo, os filhos de irmãos tratam-se, entre si, de irmãos e irmãs, e o mesmo fazem os filhos de irmãs. Os filhos de uma mulher e os de seu irmão chamam-se reciprocamente primos e primas (ENGELS, 1995, p. 27).

Apesar de os vínculos de consanguinidade usados pelos povos selvagens e bárbaros entrarem em contradição com os vínculos de parentesco conhecidos atualmente, naquelas famílias 'as designações 'pai', 'filho', 'irmão', 'irmã' não são simples títulos honoríficos, mas, ao contrário, implicam sérios deveres recíprocos, perfeitamente definidos, cujo conjunto forma uma parte essencial do regime social desses povos" (ENGELS, 1995, p. 29).

Friedrich Engels dá prosseguimento ao seu estudo definindo alguns tipos de família conforme cada estado de evolução em que se encontravam. Na família consanguínea, tida como a mais primitiva, os grupos conjugais eram distinguidos por gerações, como avós, pais e filhos. Porém, todos os avós são maridos e mulheres entre si, assim como todos os pais são maridos e esposas entre si.

\begin{abstract}
A família consanguínea, a primeira etapa da família. Nela, os grupos conjugais classificam-se por gerações: todos os avôs e avós, nos limites da família, são maridos e mulheres entre si; o mesmo sucede com seus filhos, quer dizer, com os pais e mães; os filhos destes, por sua vez, constituem o terceiro círculo de cônjuges comuns; e seus filhos, isto é, os bisnetos dos primeiros, o quarto círculo. Nessa forma de família, os ascendentes e descendentes, os pais e filhos, são os únicos que, reciprocamente, estão excluídos dos direitos e deveres do matrimônio. Irmãos e Irmãs, primos e primas, em primeiro, segundo e restantes graus, são todos entre si, irmãos e irmãs, e por isso mesmo maridos e mulheres uns dos outros. O vínculo de irmão e irmã pressupõe, por si, nesse período, a relação carnal mútua. $(O$ primeiro progresso na organização da família consistiu em excluir os pais e filhos das relações sexuais recíprocas, o segundo foi a exclusão dos irmãos.) (ENGELS, 1995, p. 39).
\end{abstract}

Engels afirma que a exclusão das relações sexuais entre pais e filhos foi o primeiro passo de progresso dentro da família. O segundo seria a exclusão das relações sexuais entre os irmãos, como demonstra o outro tipo de família tratado pelo autor, a família Punaluana.

A família Punaluana. Foi ocorrendo pouco a pouco, provavelmente começando pela exclusão dos irmãos uterinos (isto é, irmãos por parte de mãe), a princípio em casos isolados e depois, gradativamente, como regra 
geral e acabando pela proibição do matrimônio até entre irmãos colaterais. (...) Sem dúvida, nas tribos onde esse progresso limitou a reprodução consanguínea, deve ter havido um progresso mais rápido e mais completo que naquelas onde o matrimônio entre irmãos e irmãs continuou sendo uma regra e uma obrigação. Os filhos das irmãs de minha mãe são também filhos desta, assim como os filhos dos irmãos do meu pai o são também deste; e todos eles são irmãs e irmãos meus. Mas os filhos dos irmãos de minha mãe são sobrinhos e sobrinhas desta, assim como os filhos das irmãs de meu pai são sobrinhos e sobrinhas deste, e todos são meus primos e primas. (...) a proibição das relações sexuais entre irmãos e irmãs pela sociedade levou à divisão dos filhos de irmãos e irmãs, até então indistintamente considerados irmãos e irmãs, em duas classes: uns continuam sendo, como antes, irmãos e irmãs (colaterais); outros - de um lado os filhos dos irmãos, de outro os filhos das irmãs - não podem continuar mais como irmãos e irmãs, já não podem ter progenitores comuns, nem o pai, nem a mãe, nem os dois juntos; e por isso se torna necessária, pela primeira vez, a categoria dos sobrinhos e sobrinhas, dos primos e primas, categoria que não teria sentido nenhum no sistema familiar anterior (ENGELS, 1995, p. 41).

Apesar de deixar claro que com o progresso ocorreu a tendência em impedir o casamento entre parentes consanguíneos, o autor afirma que nunca houve consciência dos membros daquelas tribos da finalidade daquele impedimento: "Observamos, pois, que a tendência para impedir o matrimônio entre consanguíneos manifesta-se aqui e ali, mas de maneira espontânea, em tentativas, sem uma consciência clara dos fins objetivados" (ENGELS, 1995, p. 46).

Para o antropólogo Claude Lévi-Strauss, a proibição do incesto foi algo artificialmente criado, que possibilitou a passagem da natureza à cultura:

O certo é que nunca se insistirá o suficiente no fato de que se a organização social teve um princípio, este só pode ter consistido na proibição do incesto; isto explica-se pelo fato de que, como mostramos, a proibição do incesto não é mais do que uma espécie de remodelação das condições biológicas do acasalamento e da procriação (que não conhecem regras, como se pode ver observando a vida animal) que as compele a perpetuarem-se unicamente num marco artificial de tabus e obrigações. É ali, e só ali, que encontramos uma passagem da natureza à cultura, da vida animal à vida humana, e que podemos compreender a verdadeira essência da sua articulação (LÉVISTRAUSS, 1980, p. 34).

Lévi-Strauss foi bastante claro ao afirmar que, mesmo existindo em toda estrutura familiar a proibição de certas relações sexuais, isso varia conforme os diferentes tipos culturais:

A estrutura da família, sempre e em toda parte, faz com que certos tipos de relações sexuais não sejam possíveis ou que, pelo menos, sejam confundidas. 
É verdade que as limitações podem variar enormemente de um lugar para outro, segundo o tipo de cultura considerado (LÉVI-STRAUSS, 1980, p. 31).

Ou seja, resta claro que a proibição do incesto, apesar de ser algo universal, nem sempre fora algo ligado ao parentesco consanguíneo, já que as regras poderiam variar conforme os hábitos culturais de cada civilização. Para o autor, o fator determinante nas regras do incesto seria a "relação social" entre os indivíduos, e não necessariamente o vínculo biológico.

\begin{abstract}
A proibição do incesto, por conseguinte não se exprime sempre em função das regras de parentesco real, mas têm por objeto sempre os indivíduos que se dirigem uns aos outros empregando certo termos. Isto continua verdadeiro, mesmo nos sistemas da Oceania que permitem o casamento com uma "Irma" por classificação, mas distinguem imediatamente entre kave maori ou "irmã verdadeira" e kave kasese, "Irmã diferente", kave fakatafatafa, "Irmã posta de lado", kave i take yayae, "Irmã de um outro lugar". É a relação social, situada além do vínculo biológico, implicado pelos termos "pai", "mãe", "filho", "filha", "irmão" e "irmã" que desempenha o papel determinante (LEVÍSTRAUSS, 2011, p. 67-68).
\end{abstract}

Aliás, quanto às regras relacionadas à consanguinidade, o autor é ainda mais objetivo:

\begin{abstract}
Os especialistas em genética demonstraram se bem que os casamento consanguíneos possam provocar efeitos nocivos numa sociedade que os tenha evitado de forma coerente no passado, o perigo seria muito menor se a proibição nunca tivesse existido, porquanto isso teria dado ampla oportunidade a que os caracteres hereditários daninhos aparecessem e fossem eliminados por seleção (LÉVI-STRAUSS, 1980, p. 32).
\end{abstract}

Ou seja, seria mais vantajoso para a sociedade, em termos de evolução genética, a liberação do incesto consanguíneo do que a sua proibição. "Portanto, o perigo dos casamentos entre consanguíneos não é tanto a razão como a consequência da proibição do incesto" (LÉVI-STRAUSS, 1980, p. 32).

Para Lévi-Strauss, existe uma simples diferença entre os aspectos culturais e os naturais do ser-humano. Onde existem aspectos culturais há elaborações de regras. Já a natureza se manifesta por meio do universal, ou seja, daquilo que é constante em todos os homens. "Porque aquilo que é constante em todos os homens escapa necessariamente ao domínio dos costumes, das técnicas e das instituições pelas quais seus grupos se diferenciam e se opõem" (LÉVI-STRAUSS, 2011, p. 45).

Estabeleçamos, pois, que tudo quanto é universal no homem dependa da ordem da natureza e se caracteriza pela espontaneidade, e que tudo quanto está ligado a uma norma pertence à cultura e apresenta os atributos do relativo e do particular (LÉVI-STRAUSS, 2011, p. 45). 
É nesse aspecto que a proibição ao incesto se torna curiosa, pois, de acordo com a teoria de Lévi-Strauss, essa proibição apresentaria "os dois caracteres nos quais reconhecemos os atributos contraditórios de duas ordens exclusivas, isto é, constituem uma regra, mas uma regra que, única entre todas as regras sociais, possui ao mesmo tempo caráter de universalidade" (LÉVI-STRAUSS, 2011, p. 45-46).

A universalidade do incesto se caracteriza pelo fato de sempre ter existido algum tipo de proibição a modelos de uniões em todas as civilizações, a partir do momento em que buscaram se tornar uma civilização.

Rodrigo da Cunha Pereira afirma que "a proibição do incesto é o primeiro interdito do homem, isto é, a primeira lei de qualquer organização social e jurídica. Marca a passagem do estado da natureza para a cultura, sendo um princípio fundamental e fundante de todas as culturas do mundo ocidental" (PEREIRA, 2006, p. 26).

As sociedades primitivas sempre utilizaram processos de tentativa de coesão do grupo, que a todo momento se via ameaçado. A natureza forneceu ao ser humano a possibilidade da relação entre os sexos, porém foi a cultura que a determinou, que estabeleceu suas modalidades. A cultura determinou a regra do incesto para defender o seu papel primordial: o de garantir a existência do grupo como grupo.

Explica Claude Leví-Strauss: "O homem é um ser biológico ao mesmo tempo que um indivíduo social. Entre as respostas que dá às excitações exteriores ou interiores, algumas dependem inteiramente de sua natureza, outras de sua condição" (2011, p. 39).

Assim, percebe-se que o incesto, mesmo sendo universal, é uma regra; ou seja, é variável de acordo com a sociedade, bastando lembrar "que a proibição do casamento entre parentes próximos pode ter um campo de aplicação variável, de acordo com o modo como cada grupo define o que entende por parente próximo" (LÉVI-STRAUSS, 2011, p. 46).

LÉVI-STRAUSS concluiu que a verdadeira razão para o incesto é a mesma do princípio da divisão sexual do trabalho, que criou uma "dependência mútua entre os dois sexos, obrigando-os a perpetrarem-se e a fundar uma família, a proibição do incesto estabelece uma mútua dependência entre famílias, obrigando-as, com o fim dese perpetuarem a si mesmas, à criação de novas famílias" (LÉVI-STRAUSS, 1980, p.33).

A proibição do incesto tem logicamente em primeiro lugar por finalidade
"imobilizar" as mulheres no seio da família, a fim de que a divisão delas, ou
a competição em torno delas, seja feita no grupo e sob o controle do grupo, e
não em regime privado. (...) Considerada como interdição, a proibição do
incesto limita-se a afirmar, em um terreno essencial à sobrevivência do 
grupo, a preeminência do social sobre o natural, do coletivo sobre o individual, da organização sobre o arbitrário (LÉVI-STRAUSS, 2011, p. 83).

Assim, considerando ser a proibição do incesto a prevalência do social sobre o natural, é imperioso que tal restrição seja analisada com base nas regras sociais atuais, para que seja coerente e satisfaça o seu objetivo de manter a união do grupo; ou melhor, manter a convivência saudável em sociedade, dentro dos princípios e valores sociais atuais.

\section{A PROIBIÇÃO DO INCESTO SOB A ÓTICA DA PSICANÁLISE}

Sigmund Freud, para explicar a razão do incesto e a maneira como a relação entre pai e filho se dá, também analisou o comportamento dos homens primitivos. No estudo Totem e Tabu, o psicanalista utiliza o sistema totêmico como um tipo de metáfora para explicar a relação paterno-filial, bem como a necessidade de uma lei, de uma interdição, por parte do pai para a estruturação psíquica do filho.

Define Rodrigo da Cunha Pereira:

Totem é um animal ou, raramente, um vegetal, ou um fenômeno natural (chuva, vento, por exemplo), ou mesmo um objeto, que mantém uma relação peculiar com o clã, sendo assim, o objeto de tabus, proteção e deveres particulares. O totem é o antepassado comum do clã, ao mesmo tempo que é o espírito guardião e auxiliar. Cada clã possui seu totem, e os seus integrantes têm a obrigação sagrada de não destruí-lo. Na relação de subordinação ao totem está a base de todas as obrigações sociais e restrições morais das tribos (2003, p. 25).

Com base nesse conceito de totem, Freud relata o ocorrido no período selvagem, no qual em cada tribo um homem tinha várias mulheres e quando os filhoshomens atingiam a fase reprodutora, esses eram expulsos pelo pai da tribo, a fim de se evitar que os filhos possuíssem as suas mulheres.

Em determinado momento, os filhos expulsos da tribo, por não aceitarem mais a ordem paterna, voltavam para acabar com o próprio pai. Após assassiná-lo e cortarem seu corpo, comiam, cada um, uma parte. Com a morte do pai, os filhos passam a se identificar com ele, acreditando que absorviam sua força. Contudo, nesse momento também surgia o sentimento de culpa, de arrependimento entre os irmãos.

Recorrendo à cerimônia da refeição totêmica, podemos dar uma resposta. Certo dia, os irmãos expulsos se juntaram, abateram e devoraram o pai, assim terminando com a horda primeva. Unidos, ousaram fazer o que não seria possível pessoalmente. (Talvez um avanço cultural, o manejo de uma arma 
tenha lhes dado um sentimento de superioridade). $\mathrm{O}$ fato de haverem também devorado o morto não surpreende, tratando-se de canibais. Sem dúvida, o violento pai primevo era o modelo temido e invejado de cada um dos irmãos. No ato de devorá-lo eles realizavam a identificação com ele, e cada um aproximava-se de parte de sua força. A refeição totêmica, talvez a primeira festa da humanidade, seria a repetição e a celebração desse ato memorável e criminoso, com o qual teve início tanta coisa: as organizações sociais, as refeições morais, a religião (FREUD, 1912-1913/2013, p. 147 e 148).

Depois do assassinato do pai e do arrependimento dos filhos, percebeu-se que o problema não estaria totalmente resolvido, pois, apesar de os irmãos aliarem-se para vencer o pai e, em consequência disso, conseguirem as mulheres que desejavam, eles começaram a desejar as mesmas mulheres, tornando-se também rivais entre si.

Por desejarem viver juntos, os irmãos passaram a internalizar a regra do pai de não possuir suas mulheres -, não pela existência do pai, pois ele já estava morto, mas por uma "obediência posterior". Ou seja, aquele pai morto estava mais vivo do que nunca para seus filhos. Frise-se que foi a partir do surgimento do sentimento de culpa dos filhos que o sistema totêmico e as demais religiões subsequentes se desenvolveram, em busca de tentar tranquilizar o pai ofendido e o próprio sentimento de culpa dos filhos, seguindo o que a psicanálise conhece como obediência a posteriori.

\begin{abstract}
As primeiras prescrições e restrições morais da sociedade primitiva foram por nós concebidas como reações a um ato que deu a seus autores a noção de crime. Eles se arrependeram desse ato e decidiam que ele não poderia mais se repetir, e que sua execução não deveria trazer nenhuma vantagem. Essa criativa consciência de culpa não desapareceu entre nós. Nós a vemos atuando nos neuróticos, de forma associal, a fim de produzir novos preceitos morais, continuadas restrições, como penitência para os malfeitos cometidos e advertência para outros a cometer (...). Deste modo, os impulsos de hostilidade para o pai, a existência da fantasia com o desejo de matá-lo e devorá-lo, poderia bastar para reproduzir a reação moral que gerou o totemismo e o tabu (FREUD, 1912-1913/2013, p. 167).
\end{abstract}

A partir desse momento, houve a internalização da lei de não possuir as mulheres do pai assassinado. Daí o surgimento das primeiras leis e do próprio totem como uma organização social. Esse aspecto social do totem se fundamenta na solidariedade fraterna, na qual os irmãos e as irmãs de um clã deveriam se ajudar e se proteger. Surge aí o tabu quanto aos membros de um mesmo clã se casarem ou terem relações sexuais entre si.

Freud, amparado na criação de um mito, aborda a estrutura da lei que barra o gozo, tida na psicanálise como a "lei primordial", que possibilitou o fortalecimento da organização social, visto que os irmãos eliminaram o conflito de terem as mesmas 
mulheres do pai e passaram a buscar as mulheres de outras tribos. Daí o surgimento também da exogamia.

\begin{abstract}
A Lei simbólica está referida à Psicanalise como a noção de Lei primordial, como fundadora das leis sociais. Ela é estrutural, ou seja, independe do lugar, do momento histórico e da constituição social. Alei simbólica equivale ao que Freud nomeou como a Lei da interdição ao incesto, cujo representante é o pai que impede o filho de se deitar com a mãe (DUARTE, 2009, p. 92).
\end{abstract}

Para Freud, o sentimento de culpa atua na sociedade como inibidor do agir. Ele cria preceitos morais e restrições, com o intuito de punir os atos malfeitos e de advertir para os eventuais atos delituosos que se possa cometer.

\begin{abstract}
O Direito, ou melhor, as leis, não surgiram da razão do homem baseado em que isto é justo e aquilo é injusto. Elas surgiram dos cultos religiosos dos povos mais primitivos. Elas nasceram como "consequência direta e necessária da crença: era a própria religião, aplicada às relações dos homens entre si” (PEREIRA, 2003, p. 22).
\end{abstract}

Freud, para tentar explicar a ideia atual de repulsa ao ato sexual entre os parentes consanguíneos, fez menção às ideias de alguns autores, entre eles Westermarck (1906-08) e J. G. Frazer (1910). Após discorrer sobre tais teorias, concluiu que, em verdade, não existe no ser humano uma aversão natural ao incesto. Tal tabu foi construído socialmente, pois tudo indica que os primeiros interesses sexuais dos seres humanos são de caráter incestuoso.

\begin{abstract}
A esta preciosa argumentação de Frazer posso acrescentar que a experiência da psicanálise mostra ser insustentável a suposição de uma inata aversão ao incesto. Ensina, pelo contrário, que os primeiros impulsos sexuais dos jovens seres humanos são de caráter incestuosos, e que tais impulsos reprimidostêm, como forças motrizes de neuroses posteriores, um papel que não se pode exagerar (FREUD, 1912-1913/2013, p. 128).
\end{abstract}

Assim como Claude Lévi-Strauss, Freud concluiu que o incesto é uma regra universal; ou seja, foi criado pela cultura, mas está presente desde os primórdios da sociedade. Para o psicanalista, em toda lei há um desejo que se contrapõe a ele, uma vez que não há a necessidade de proibir algo que ninguém deseja fazer.

No caso da proibição do incesto, verifica-se que o ser humano optou por abrir mão do seu desejo individual em prol da manutenção da vida em sociedade. Entretanto, as modalidades dessas proibições, que ensejariam a manutenção da vida em grupo, sempre foram manipuladas conforme a sociedade em questão.

Dessa forma, é imperioso questionar se os impedimentos das relações sexuais entre parentes consanguíneos realmente representam os valores e costumes atuais de 
uma sociedade que, por meio dos avanços da biotecnologia e da mudança de paradigma do Direito de Família, dissociou a relação paterno-filial do vínculo genético.

\title{
3. PATERNIDADE E MATERNIDADE: UMA FUNÇÃO
}

Estudos mais recentes da antropologia, "muito contribuíram para desconstruir a concepção dos conceitos de família, filiação e parentesco enquanto fenômenos naturais, apontando para estes como criações humanas" (BRITO, 2008, p. 265).

\begin{abstract}
Por meio de exemplos descritos pela Antropologia, se observa que a designação dos lugares estruturais de pai e de mãe podem variar em distintas culturas, o que indica não ser o determinismo biológico que os fixa. Há, no entanto, uma referência simbólica nesses lugares genealógicos, fazendo com que as dimensões sociais e privadas com referência à paternidade estejam interligadas, sendo necessário que o campo social sustente a importância de ser pai no âmbito privado (BRITO, 2008, p. 265).
\end{abstract}

Tony Anatrella afirma: "A própria palavra "pai” não designa o genitor, o indivíduo pai, mas aquilo que decorre da "função paternal", isto é, o papel simbólico que será representado em nome dessa figura" (2001, p. 39).

Ou seja, o genitor, aquele que gera o indivíduo ou, em outros termos, o seu ascendente biológico, não será necessariamente o pai, podendo qualquer pessoa que assuma tal função ser denominada pelo termo pai.

A psicanálise indica que a imagem paterna não é formada exclusivamente por aquele que ele é na realidade, pela maneira como ele é sentido pelo filho e muito menos pela forma como ele é imaginado por este. Essa imagem acaba sendo o resultado da conjugação dessas três faces. Porém, o pai que existe na realidade, ou seja, aquele que realmente exerce a função, acabará interferindo diretamente nas duas outras noções sobre essa imagem (ANATRELLA, 2001)

\begin{abstract}
A imagem do "pai" é o resultado de uma alquimia psíquica elaborada pelo indivíduo a partir da infância. Ela se forma a partir de inúmeros elementos: de inicio o pai real, o genitor, ou ainda o pai nutridor, aquele que se ocupa da criança; depois o pai psíquico tal como a criança o percebe e o vivencia subjetivamente independentemente daquele que é o pai real. Por fim, o pai imaginário, carregado de expectativas, decepções e temores, mais relacionados com os conflitos intrapsíquicos do individuo do que com a realidade. É, todavia, bem evidente que a atitude do pai na realidade vai influir sobre a organização dessa imagem, que permanece, portanto, essencialmente, uma imagem compósita (ANATRELLA, 2001, p. 39).
\end{abstract}

"A primeira concepção sustenta-se sobre um paradoxo: o pai real não passa jamais de uma conjectura. A função paterna reside nessa dúvida” (HADDAD, 1992, p. 
251). Isso porque essa identidade biológica do pai, antes do desenvolvimento do exame genético, sempre foi uma suposição. Assim, pai, em verdade, era o que exercia a função de pai, e não necessariamente aquele que transmitia aos descendentes seus genes.

Entretanto, antes dos testes tão precisos que existem hoje a garantia da verdadeira identidade do pai sempre foi uma questão constante. Diante disso, Gerard Haddad coloca que, na realidade, aquele que está exercendo a função de pai não quer saber se é ou não o ascendente biológico do filho; ele quer acreditar na palavra da mulher, sendo ele próprio o responsável por garantir o seu papel de pai.

Não haveria, ainda assim, ao menos uma possibilidade, mesmo experimental,
de garantir a verdade sobre o pai real? Pergunta um rabi. Não se poderia, por
exemplo, encarcerar um homem e uma mulher numa cela, para que se tenha
certeza de sua filiação? - Bobagens!, retruca outro - Viste alguma vez um
cárcere sem carcereiro? A fé atribuída à palavra da mulher é aqui inevitável,
e sem dúvida alguma, inquestionavelmente, nenhuma certeza biológica
jamais sobrepujará essa falha. Um pai situa-se por princípio nessa dimensão,
a da confiança numa palavra, e, portanto no simbólico que ele próprio vem
garantir (HADDAD, 1992, p. 252).

Ocorre que o filho precisará da presença física do pai para conseguir criar sua identificação, caso contrário não terá "acesso à simbólica paternal” (ANATRELLA, 2001, p. 40). Também nesse sentido discorre Marlouve Moreno Sampaio Santos, alegando que a paternidade só existe quando efetivamente exercida:

Hoje, o pensamento jurídico e psicanalítico vem acenando que a paternidade só existe quando efetivamente exercida, ou seja, que o pais verdadeiramente adota o filho. Jamais uma norma ou lei conseguirá, por si só, transformar o genitor na figura de pai. É nesse cenário que emerge a figura da paternidade socioafetiva, como aquela que enxerga a paternidade não apenas como um fato da natureza, mas, principalmente, como um fato cultural, que vai muito além do mero laço biológico existente (SANTOS, 2009, p .350).

Lenita Pacheco Lemos Duarte afirma que "como aponta Lacan, a paternidade é uma função exercida ou um lugar ocupado por alguém que não é necessariamente o pai biológico, mas a quem caberia a tarefa de transmissão simbólica da Lei e sua articulação com o desejo" (2009, p. 105).

Não existem, até nossos dias, sociedade humana que sejam fundadas unicamente sobre a simples consideração da procriação biológica ou que lhe tenham atribuído a mesma importância que a filiação socialmente definida. Todos consagram a primazia do social - da convenção jurídica que funda o social - sobre o biológico puro. A filiação não é, portanto, jamais um simples derivado da procriação. É uma terceira constante (HERITIER, 2000, p. 102). 
A psicanálise afirma que serão pai e mãe aqueles indivíduos a quem é atribuído o nome; ou seja, aqueles que são reconhecidos pela sociedade como pais e mães. Assim, não necessariamente o procriador será reconhecido como o pai. Isso dependerá de aspectos culturais.

O pai, para nós, é, ele é real. Mas, não nos esqueçamos de que ele só real para nós na medida em que as instituições lhe conferem, eu nem diria seu papel e sua função de pai - não se trata de uma sociológica -, mas seu nome de pai. Que o pai seja, por exemplo, o verdadeiro agente da procriação não é, de maneira alguma, uma verdade da experiência (LACAN, 1957-1958/1999, p. 186-187).

Essa metáfora paterna, em que pai será aquele que exerce a função de pai, pode ser verificada em casos particulares ocorridos em algumas sociedades, em que, combase em sistemas simbólicos de representações, dissociam-se as funções do genitor e do pai, comprovando-se que os laços biológicos não são determinantes.

\begin{abstract}
A fisiologia, o sexo, a idade etc. são apenas parâmetros reelaborados e reinterpretados nesse cadinho que é o sistema simbólico de representações ativo no seio desta ou daquela sociedade. Diante de modalidades tão artificiais de atribuição a cada sexo dos papeis no processo da parentalidade, não se pode deixar de constatar que não são os laços biológicos que são determinantes, e sim a utilização que deles fazem as diferentes ideologias. E a cultura, neste caso, é uma entidade social e fantasmática complexa, que passa por diferentes conceitos operativos (PARSEVAL, 1986, p. 43).
\end{abstract}

HERITIER relata que no âmbito da cultura do povo africano Nuer, que vive no Sudão, quando as mulheres, após o casamento, descobrem que são estéreis retornam à sua linhagem de origem, onde serão consideradas como homens. Assim, após adquirirem o status masculino passam a ter direito, assim como os homens da família, às transferências de gado realizadas em decorrência dos casamentos das mulheres da sua família (2000, p. 109).

De volta à casa de seus irmãos, a mulher estéril se beneficia, então, na qualidade de tio paterno, de parte do gado da compensação dada para suas sobrinhas. Quando ela, dessa forma, constitui um capital, ela pode por sua vez fornecer uma compensação matrimonial e obter uma esposa da qual ela se torna marido. Essa relação conjugal não leva a relações homossexuais: a esposa serve seu marido e trabalha em seu benefício. A reprodução é assegurada graças a um criado, a maior parte das vezes de uma etnia estrangeira, que cumpre tarefas pastorais mas assegura também o serviço de cama junto à esposa. Todas as crianças vindas ao mundo são do 'marido', que a transferência do gado designou expressamente, segundo a lei social que faz a filiação. Elas portam o seu nome, chamam-na 'pai', a respeitam e não se estabelece nenhum laço particular com o seu genitor (...)” (HERITIER, 2000, p. 109). 
Ou seja, a mulher estéril, sendo considerada como homem, começa a adquirir patrimônio próprio e, via de consequência, também poderá obter uma esposa. Por não se tratar de uma relação homossexual, a esposa procriará com um criado e os filhos advindos dessa relação serão da mulher estéril, considerada por todos como o marido e pelos filhos como o pai. Já com o genitor - no caso, o criado -, os filhos não terão qualquer tipo de relação (HERITIER, 2000, p. 109).

A dissociação da figura de mãe e genitora também é verificada no caso dos Tupi-Kawabi, no Brasil, em que "as esposas de um mesmo homem, que são às vezes parentes consanguíneos" (HERITIER, 2000, p. 110) criam todas as crianças daquele homem, como se fosse um tipo de maternidade coletiva, sem se importarem se as crianças, das quais elas se ocupam, lhes pertencem ou não (LEVI-STRAUSS, 1980).

Mesmo tratando-se de casos extremos e singulares, é importante perceber que "não existe dúvida para nenhum dos atores sociais sobre a identidade do pater, aquele por quem passa a filiação" (HERITIER, 2000, p. 112).

\footnotetext{
Quando o consenso social se estabelece, a filiação é definida por lei e pode viver em harmonia consigo mesmo e com os outros, dissociando perfeitamente as funções do genitor e do pater, da genitora e da mater, pelo menos nas situações onde a criança não é privada do amor e do apoio que tem direito de esperar de seus pais de fato (HERITIER, 2000, p. 113).
}

Assim, a interpretação da paternidade e da maternidade vista como um lugar a ser ocupado, ou um significante, enseja a conclusão de que esse lugar poderá ser ocupado por qualquer um que exerça ou venha a exercer essa função, transcendendo os elementos biológicos. "Portanto, o pai pode ser uma série de pessoas ou personagens: o genitor, o marido da mãe, o amante oficial, o companheiro da mãe, o protetor da mulher durante a gravidez, o tio, o avô, aquele que cria (...), enfim, aquele que exerce uma função de pai” (PEREIRA, 2003, p. 121).

Dessa forma, a análise dos parâmetros de parentesco em relação aos ascendentes revela que, independentemente das designações dadas aos vínculos entre os parentes, o mais importante é o que cada vínculo significa dentro do contexto social em que o homem se situa.

\section{OS IMPEDIMENTOS MATRIMONIAIS NO ORDENAMENTO BRASILEIRO}


No Código Civil de 2002, o art. 1.521 elenca, taxativamente, as pessoas que não podem se casar em determinados casos. Essas "situações são tidas como de maior gravidade, envolvendo ordem pública, além dos interesses das próprias partes" (TARTUCE; SIMÃO, 2010, p. 67).

Dos sete incisos tratados no art.1521 do $\mathrm{CC}^{1}$, cinco são impedimentos resultantes de relações de parentesco, "decorrentes de relações parentais de consanguinidade (incisos I e IV), afinidade (incisos II e III) e de adoção (inciso V)" (FARIAS; ROSENVALD, 2014, p. 202). Quem, ainda assim, desobedece à vedação legal e se casa estará indo contra um preceito de ordem pública, formalizando um casamento nulo.

\begin{abstract}
As hipóteses contidas no Código Civil (art.1.521) para os impedimentos matrimoniais são taxativas, representam numerus clausus e, por isso, não há possibilidade de ampliá-las sem que haja lei dispondo nesse sentido. Tais impedimentos ora são fundamentados em aspecto moral, ora biológico e, às vezes, nos dois aspectos. São considerados defeitos graves, por isso o casamento que se realiza desrespeitando-os é considerado nulo. Além disso, de acordo com o art.237 do Código Penal, é considerado crime contrair casamento conhecendo a existência de impedimento que lhe cause nulidade absoluta (ALMEIDA; RODRIGUES JUNIOR, 2012, p .113).
\end{abstract}

Esse preceito de ordem pública diz respeito a uma norma cogente, que, nas palavras de Pontes de Miranda (1999), "é o direito que a vontade dos interessados não pode mudar. Uma vez composto o suporte fático, a regra jurídica incide, ainda que o interessado ou todos os interessados não o queiram" (MIRANDA, 1999, p. 105). Assim, os impedimentos matrimoniais "são entraves, obstáculos, impostos pela legislação, com o fito de limitar a natural faculdade de casar que é reconhecida às pessoas" (FARIAS; ROSENVALD, 2014, p. 198).

\footnotetext{
${ }^{1}$ Art. 1.521. Não podem casar:

I - os ascendentes com os descendentes, seja o parentesco natural ou civil;

II - os afins em linha reta;

III - o adotante com quem foi cônjuge do adotado e o adotado com quem o foi do adotante;

IV - os irmãos, unilaterais ou bilaterais, e demais colaterais, até o terceiro grau inclusive;

$\mathrm{V}$ - o adotado com o filho do adotante;

VI - as pessoas casadas;

VII - o cônjuge sobrevivente com o condenado por homicídio ou tentativa de homicídio contra o seu consorte. (BRASIL, 2002).
} 
Apesar da reprovação pela Lei Civil, o Direito Penal, em louvável posicionamento (em especial nos tempos atuais em que se apregoa o Direito Penal mínimo), não tipificou o incesto como crime, inexistindo sanção penal para a eventual ocorrência de relacionamento sexual entre ascendente e descendente (FARIAS; ROSENVALD, 2014, p. 204).

A legislação brasileira também deixa claro que quando uma criança é entregue para adoção seus pais biológicos serão destituídos do poder familiar. Com isso, todos os vínculos entre os pais biológicos e a criança serão extintos. Curiosamente, a única regra que continua sendo válida entre a criança e seus parentes biológicos é a dos impedimentos matrimonias.

Porém, conforme já exposto, atualmente os vínculos consanguíneos não representam necessariamente a existência de alguma relação social, mesmo que aqueles indivíduos tenham assumido ou exercido o papel determinado por aquele parentesco.

Ou seja, nem sempre os pais biológicos criaram alguma aproximação com seus filhos mediante o exercício da função de pai e da função de mãe. No mesmo sentido, irmãos biológicos podem nunca ter tido contato durante suas vidas. Nos casos de adoção e, até mesmo, de inseminação artificial heteróloga, nenhum vínculo socioafetivo é criado entres os parentes biológicos. Nesse contexto, o impedimento matrimonial decorrente do parentesco consanguíneo se esvazia por completo.

É fundamental compreender que a proibição do incesto foi criada para a manutenção da vida em grupo. Isso resulta na necessidade de convívio e relação social entre os membros desse grupo, caso contrário tal proibição não fará sentido e não será reconhecida pelos seus membros.

\begin{abstract}
Deveres morais de responsabilidade e de consideração para com o irmão não devem ser justificados apenas pelo fator biológico de genes compartilhados. Em vez disso, esses direitos morais devem ter uma base nos detalhes da relação individual, na história pessoal prévia. Se não há passado mútuo relevante que moldou uma vulnerabilidade e dependência do parceiro mais fraco, a situação não é diferente da situação padrão de dois estranhos que se conhecem como adultos, cada pessoa com seu próprio pacote de história pessoal e possíveis vulnerabilidades (HDRNLE, 2014, p. 99, tradução Nossa)

2
\end{abstract}

\footnotetext{
${ }^{2}$ Moral duties of responsibility and considerateness for one's sibling are not to be justified by merely pointing to the biological fact of shared genes. Rather, such moral duties must have a base in the details of the individual relationship, in their personal prior history. If there is no relevant mutual past that has shaped the weaker partner vulnerability and dependence, the situation is not different from the standard situation of two strangers who get to know each other as adults, each person with her own package of personal history and possible vulnerabilities.
} 
Muito em decorrência do seu caráter moral e religioso, a proibição do incesto é mantida sob fundamentos vagos de proteção à família, de proteção da prole advinda dessas relações - tendo em vista a maior predisposição genética para doenças e malformações - e de proteção da moral e dos bons costumes da sociedade, sem uma verdadeira análise sociológica desses impedimentos.

\footnotetext{
Para abordar esse ponto, deve ser feita uma distinção entre as expectativas sociais (demandas morais convencionais) e raciocínio moral que podem ser suportados com razões coerentes (demandas morais fundamentadas). Se alguém procurar por razões que poderiam apoiar a conclusão de "incesto adulto é sempre moralmente errado", chegaríamos em possíveis pontos de aproximação aos comandos religiosos. Argumentos desse tipo, no entanto, apenas convencem aqueles que compartilham crenças metafísicas, como crenças sobre a existência de seres sobrenaturais (nas religiões monoteístas, Deus), a existência de comandos emitidos por elas, e sua natureza vinculativa. Tais premissas metafísicas são inadequadas e tais premissas metafísicas são inadequadas em contextos laicos. Abordagens mais promissoras da moralidade fundamentada são justificadas em deveres morais dos seres humanos com outros seres humanos (HDRNLE, 2014, p. 98, tradução nossa).
}

A constante proibição do incesto em todas as sociedades que já existiram até então é justificada pela opção do ser humano de viver em grupo, de abrir mão dos desejos individuais e de buscar a melhor forma de manter a união dos seus membros. Dessa forma, com base nas relações de parentescos que anteriormente representavam o verdadeiro papel que cada membro exercia naquele grupo foram estabelecidas também as regras do Incesto.

Ocorre que se antes o parentesco representava papéis ou funções exercidas dentro do núcleo familiar, atualmente a possibilidade da investigação genética de laços de descendência, a evolução das técnicas de inseminação artificial e sua adoção no ordenamento jurídico dissociaram por completo o vínculo biológico dos papéis exercidos no contexto familiar.

A partir dessa dissociação de conceitos, necessário se torna promover a remodelação das regras de proibição do incesto e, consequentemente, das regras de impedimento matrimonial.

O impedimento matrimonial não deve ser justificado com base nos laços biológicos, porque não serão os dados genéticos que irão influenciar a autonomia privada do casal incestuoso, e sim a relação social existente entre eles. Dessa forma, se não houver qualquer tipo de convivência entre os parentes consanguíneos nem o 
exercício de uma função ou de um papel que represente aquele parentesco, mesmo existindo vínculo biológico, não há justificativa para o impedimento.

Os estudos da psicanálise reconhecem que a figura dos genitores é funcionalizada; ou seja, pai e mãe são aqueles que exercem de fato a função de pai ou de mãe. São aqueles reconhecidos internamente e externamente ao núcleo familiar como pai ou mãe, sendo que tal construção se dará na convivência cotidiana e paulatina.

\begin{abstract}
O pai, para nós, é, ele é real. Mas, não nos esqueçamos de que ele só real para nós na medida em que as instituições lhe conferem, eu nem diria seu papel esua função de pai - não se trata de uma sociológica -, mas seu nome de pai. Que o pai seja, por exemplo, o verdadeiro agente da procriação não é, de maneira alguma, uma verdade da experiência (LACAN, 1957-1958/1999, p. 186-187).
\end{abstract}

A verdadeira razão que justifica o impedimento de casamento entre parentes próximos é o fato de que a influência que os papéis de pai ou mãe, filho ou filha, irmã ou irmão, de fato exercidos, pode gerar na opção por um relacionamento incestuoso. Isso se evidencia quando, socialmente, existe um papel de poder e submissão entre pais, filhos e irmãos, o que poderá inviabilizar o parceiro mais influenciável de fazer uma escolha saudável e independente em relação ao parceiro mais influente.

\begin{abstract}
Raciocínio semelhante se aplica às relações pai-filho (note novamente, isso é visto como uma relação social; não importa se é a paternidade biológica). Os seguintes fatores são importantes: a intensidade da relação pai-filho, suas características essenciais de desigualdades e dependências, e o fator tempo, isto é, uma longa prática que tenha inevitavelmente enraizada na sua estrutura esse relacionamento ao longo de muitos anos. O último ponto é crucial: em geral, se duas pessoas anteriormente desiguais interagirem novamente em fases posteriores de suas vidas, pode ser possível transcender o status quo e reestruturar a relação, mas isso é improvável se o relacionamento é aquele entre pai e filho. Sob tais condições, o consentimento "da criança" deve ser
\end{abstract}

\footnotetext{
${ }^{3}$ Similar reasoning applies to parent-child relationships (note again, this is seen as a social relation; it does not matter if parenthood is biological). The following factors are important: the intensity of the parent-child relationship, its features of essential inequalities and dependencies, and the time factor, that is, a long practice that has inescapably ingrained these structures into the relationship over many years. The latter point is crucial: in general, if two formerly unequal persons interact again at later stages in their lives, it might be possible to transcend the status quo and to restructure the relationship, but this is unlikely if the relationship is the one between parent and child. Under such conditions, the "child's" consent should be evaluated as deficient even if the child is now legally an adult. Thus, the criminal law may prohibit a parent who has raised a child (for significant time periods during childhood) from having sexual relations with this child, even if the sex begins after the child is a legal adult. But such consentbased reasoning does not support a provision against incest that is based on the merely biological relationship. Biological descent as such (consider cases where adopted children search for their biological parents) does not suffice to render adult consent invalid. And the foregoing considerations cannot straightforwardly be transferred to siblings. The decisive factor is whether the common past has been haped by extraordinary dependence and submission of the younger one; this describes the situation between child and parent, but not the ordinary modes of social interaction between siblings.
} 
avaliado como deficiente, mesmo que a criança seja agora legalmente um adulto. Assim, o direito penal pode proibir um pai que tenha criado uma criança (por período de tempo significativo durante a infância) de ter relações sexuais com essa criança, mesmo que o sexo comece depois que a criança se torne legalmente um adulto. Mas esse raciocínio baseado em consentimento não suporta uma disposição contra o incesto que seja baseado na relação meramente biológica. Ascendência biológica como tal (considerar os casos em que as crianças adotadas procuram seus pais biológicos) não é suficiente para tornar o consentimento adulto inválido. E as considerações anteriores não podem diretamente ser transferidos para irmãos. $O$ fator decisivo é se o passado comum tem sido moldado pela extraordinária dependência e submissão do mais novo; isto descreve a situação entre pais e filhos, mas não os modos normais de interação social entre irmãos (HDRNLE, 2014, p. 9192, tradução nossa). ${ }^{3}$

Além disso, a justificativa com base na eugenia não pode mais ser aceita tendo em vista os avanços tecnológicos, que, inclusive, podem informar aos nubentes a probabilidade de eles terem ou não filhos com alguma deficiência, lembrando que a procriação não é mais um requisito ou elemento fundamental para o casamento. Ademais, todos os casais quando procriam assumem um risco natural de ter ou não filhos com algum problema genético, e isso não é fundamento legítimo para impedi-los de se casarem.

No Estado laico e democrático atual, em que a família deve ser um ambiente propício ao livre e pleno desenvolvimento das pessoas, seus membros devem ter a liberdade de manifestarem a sua vontade, principalmente em relação àquela pessoa com quem desejam se casar.

A liberdade de escolher livremente com quem viver uma união afetiva só deve ser limitada em prol da viabilidade da vida em sociedade, que só poderá ser ameaçada quando o grau de intimidade e convivência entre seus membros for capaz de influenciar suas escolhas quanto ao seu parceiro.

Em síntese, só deverá existir uma interdição, um obstáculo, nas relações em que se identifica algum grau de relação social, independentemente de laços consanguíneos. Assim, não devem ser mantidas restrições ao direito de se casar com base em preceitos morais, religiosos e, muito menos, em decorrência de vínculos exclusivamente consanguíneos.

Por essa razão, os impedimentos matrimoniais atuais deveriam ser revistos, mantendo-se tais restrições estritamente àqueles casos em que houve um exercício real da função decorrente do parentesco entre o casal e para os casos de incesto que se iniciaram quando pelo menos uma das partes ainda era menor de idade, tendo esse fato, provavelmente, viciado o seu discernimento. 


\section{CONCLUSÃO}

Verificou-se que a proibição do incesto, apesar de ser algo universal, sempre apresentou diversidade quanto a suas regras, conforme os hábitos culturais de cada civilização, dissociando-se frequentemente do parentesco consanguíneo. Com base nacultura, determinaram-se as modalidades do incesto com o objetivo primordial de garantir a existência do grupo como grupo.

$\mathrm{Na}$ psicanálise, a proibição do incesto é a lei que barra o gozo, a Lei Primordial, que possibilitou o fortalecimento da organização social, visto que eliminou o conflito entre os membros de uma família de disputarem as mesmas mulheres, passando a buscar as mulheres de outras famílias. Assim, verifica-se que o homem optou por abrir mão do seu desejo individual em prol da manutenção da vida em sociedade.

As modalidades de incesto sempre estiveram atreladas às modalidades de parentesco em conformidade com as regras culturais da sociedade em questão. Por essa razão, para se analisar o incesto na atualidade é fundamental analisar as relações de parentesco que existem hoje.

Ao se analisarem os parâmetros de parentesco em relação aos ascendentes, percebe-se que, independentemente das designações dadas aos vínculos entre os parentes, o mais importante é o que cada vínculo significa no contexto social em que o homem se situa. Atualmente, os vínculos consanguíneos não representam necessariamente a existência de alguma relação social, muito menos que aqueles indivíduos assumiram ou exerceram o papel determinado por aquele parentesco.

Fato é que nem sempre os pais biológicos criaram alguma aproximação com seus filhos no exercício da função de pai ou de mãe. No mesmo sentido, irmãos biológicos podem nunca ter tido contato durante suas vidas. Nos casos de adoção e, até mesmo, de inseminação artificial heteróloga, nenhum vínculo socioafetivo é criado entres os parentes biológicos.

Se a proibição do incesto foi criada para a manutenção da vida em grupo, isso requer um convívio e uma relação social entre os membros desse grupo para que tais proibições façam sentido e sejam reconhecidas como válidas pelos seus membros.

Nesse contexto, os impedimentos matrimoniais decorrentes do parentesco consanguíneo, elencados no art.1521 do CC, se esvaziam por completo. A justificativa 
com base na eugenia não pode mais ser aceita tendo em vista os avanços tecnológicos. Só deverá existir uma interdição, um obstáculo, nas relações em que se identifica algum grau de relação social, independentemente de laços consanguíneos.

Assim, as regras atuais de incesto devem ser revistas, para se restringir apenas às relações entre parentes que estabeleceram algum tipo de relação social, não devendoser mantidas restrições ao direito de se casar com base em preceitos morais, religiosos e muito menos em decorrência de vínculos consanguíneos.

\section{BIBLIOGRAFIA}

ALMEIDA, Renata de Barbosa, RODRIGUES, Walsir Edson júnior. Direito Civil: familia. 2.ed. São Paulo: Atlas, 2012.

ANATRELLA, Tony. A diferença interdita: sexualidade, educação, violência. Tradução de Maria Stela Gonçalves e Adail Ubirajara Sobral. São Paulo: Edições Loyola, 2001.

BRASIL. Código Civil (2002). In: ANGHER, Anne Joyce (Org.). Vade mecum acadêmico de direito RIDEEL.14.ed. atual e ampl. São Paulo. RIDEEL, 2012.

BRITO, Leila Maria Torraca de. Contestação de paternidade e a segurança da filiação. In: PEREIRA, Rodrigo da Cunha(Org.). Família e solidariedade. Rio de Janeiro: IBDFAM - Lumen, 2008.

DUARTE, Lenita Pacheco Lemos. A guarda dos filhos na família em litígio: uma interlocução da Psicanálise com o Direito. 3.ed. Rio de Janeiro: Editora Lumen Juris. 2009.

ENGELS, Friedrich. A origem da Família, da propriedade privada e do Estado (1884). 13 ${ }^{\mathrm{a}} \mathrm{ed}$. Rio de Janeiro: Bertrand Brasil, 1995.

FARIAS, Cristiano Chaves de; ROSENVALD, Nelson. Curso de Direito Civil: direito das famílias. Vol.6. 6ª ed. Salvador: Editora Jus Podivm, 2014.

FREUD, Sigmund. Totem e Tabu: algumas concordâncias entre a vida psíquica dos homens primitivos e a dos neuróticos (1912-1913). Trad. Paulo César de Souza. $1^{\mathrm{a}}$ ed. São Paulo: Penguin Classics Companhia das Letras, 2013.

HADDAD, Gérard. O filho ilegítimo: fontes talmúdicas da psicanálise. David 1. Bogomoletz (trad.) Rio de Janeiro: Imago Ed., 1992.

HÉRITIER, Françoise. A coxa de Júpiter: reflexões sobre os novos modos de procriação. Marcia Mello, Cordélia Freitas e Sõnia Dourado (trad.). Estudos Feministas. Ano n.8. 2000, p.98-114. 
HERNLE, Tatjana.Consensual adult incest: a sex offense? New Criminal Law Review, Vol. 17, Number i. 2014, p.76-102. Disponível em:

http://heinonline.org/HOL/Page?handle=hein.journals/bufcr 17\&div=7\&collection=jour nals\&set_as_cursor $=0 \&$ men $\_$tab $=$srchresults\&terms $=$Tatjana|Hernle\&type $=$matchall.

Acesso em 12-12-2014.

LACAN, Jacques. O seminário, livro 5: as formações do inconsciente (1957-1958).

Tradução de Vera Ribeiro. Rio de Janeiro: Jorge Zahar Ed. 1999.

LACAN, Jacques. Os complexos familiares na formação do indivíduo. Marco

Antonio Coutinho Jorge; Potiguara Mendes da Silveira Jr. (trad.). Rio de Janeiro: Jorge Zahar Editor, 1987.

LÉVI-STRAUSS, Claude. A Família: origem e evolução. Porto Alegre: Editorial Villa Martha ltda., 1980.

LÉVI-STRAUSS, Claude. Estruturas elementares do parentesco (1982). Mariano Ferreira (trad.). $6^{a}$ ed. Petrópolis: Vozes, 2011.

LÉVI-STRAUSS, Claude. O pensamento selvagem (1989). Tradução de Tânia Pellegrini. 12 ed. São Paulo: Papirus, 2011.

MIRANDA, Pontes de. Tratado de Direito Privado. Atualizada por Vilson Rodrigues Alves. Tomo 1, 1. ed. Campinas: Bookseller, 1999.

MIJOLLA, Alain de. Dicionário internacional da psicanalise: conceitos, noções, biografias, obras, eventos, instituições. Álvaro Cabral (trad.). Rio de janeiro: Imago ed., 2005.

PARSEVAL, Geneviève Delaisi. A parte do pai. Thereza Cristina Stummer (trad.). Porto Alegre: L\& PM, 1986.

PEREIRA, Rodrigo da Cunha. A primeira lei é uma lei de direito de família: A lei do pai e o fundamento da lei. In GROENINGA, Giselle Câmara; PEREIRA, Rodrigo da Cunha (coord). Direito de Família e Psicanálise: rumo a uma Nova epistemologia. Rio de Janeiro: Imago, 2003.

PEREIRA, Rodrigo da Cunha. Princípios fundamentais e norteadores para a organização jurídica da família. Belo Horizonte: Del Rey, 2006.

SANTOS, Marlouve Moreno Sampaio. Reflexões sobre a paternidade nas relações familiares sob a ótica do direito e da psicanálise. In: BASTOS, Eliene Ferreira; ASSIS, Arnoldo Camanha de e.(Coords). Família e Jurisdição III. Belo horizonte: Del Rey, 2009. p.321-352.

TARTUCE, Flávio; SIMÃO, José Fernando. Direito Civil: Direito de Família. Rio de Janeiro. Método, 2010.

TREVISAN, Rosana. Moderno dicionario michaelis da lingua portuguesa.

Disponível em: 
http://michaelis.uol.com.br/moderno/portugues/index.php?lingua=portuguesportugues\&palavra=incesto; Acesso em: 12/07/2015. 